\title{
Numerical groundwater flow modeling for managing the Gabes Jeffara aquifer system (Tunisia) in relation with oasis ecosystems
}

\author{
J.F. Vernoux ${ }^{1}$, F. Jarraya Horriche ${ }^{2}$, R. Ghoudi ${ }^{3}$ \\ ${ }^{1}$ BRGM, F-45060 Orléans, France, jf.vernoux@brgm.fr \\ ${ }^{2}$ Carthage University, CERTE, Laboratory of Georesources, - BP 273-8020 Soliman, Tunisia, \\ faten.horriche@topnet.tn \\ ${ }^{3}$ CRDA - 6019 Gabes, Tunisia, r.ghoudi@gmail.com
}

\begin{abstract}
The Gabes Jeffara aquifer system, in southeastern Tunisia, is essentially recharged by rainfall infiltration and by groundwater inflow from the Intercalary Continental aquifer in the northwest. The increase in groundwater pumping for irrigation in recent decades has induced a serious decrease in groundwater levels, depletion of springs and degradation of oasis ecosystems. A multidisciplinary study was carried out to better understand the behavior of oasis ecosystems and aquifer systems and to provide tools and recommendations for water resources management. An important part of the study was devoted to developing a hydrodynamic flow model of the Jeffara aquifer system, which can be used as a future groundwater management tool considering different recharge or exploitation scenarios. This model was built with Processing Modflow, gathering data on geology, hydrogeology, hydrology, rainfall, piezometry, withdrawals and spring flow rates. The model was calibrated in steady state with reference to the piezometric levels measured in 1970 and in transient state for the period 1972-2014, using records from more than 200 wells and piezometers. The analysis of current and future water consumption was carried out with existing data, processed satellite images and farmer surveys. This analysis was used to define water demand scenarios combined with scenarios of decreased groundwater withdrawal, reinforced groundwater recharge and use of alternative water resources. The scenarios tested with the model show that the situation will be critical in less than 25 years without radical measures to reduce groundwater withdrawals by at least $60 \mathrm{MCM} / \mathrm{y}$.
\end{abstract}

Keywords: Arid regions, Numerical modeling, Over-abstraction, Groundwater management, Tunisia. 


\section{Introduction}

Significant groundwater resources are located in southern Tunisia, but these resources, which are the main supplies in the Middle East and North Africa (MENA) coastal region, are under growing pressure in response to population and economic growth (Lezzaik and Milewski 2018). Most groundwater is taken from deep wells, which provide considerable economic advantages to the users for irrigation, domestic and industrial water supplies. Due to the climatic conditions, no sustainable agricultural production is possible without irrigation. Approximately $25 \%$ of the total area of the Gabes Jeffara plain is used for agricultural purposes with 151 irrigated areas covering 22,000 ha (Vernoux et al. 2017a). All water is drawn exclusively from shallow and deep aquifers. Since the end of the nineteenth century, many springs have been used to supply all water needs for agricultural and domestic use. Currently, all of these springs have dried up, and groundwater from deep aquifers has become the major water supply source. Groundwater resources in the Gabes region are less renewable resources. These resources are contained in Mio-Pliocene sands, Senonian limestones, Turonian dolomites, and Jurassic limestones (Vernoux et al. 2017b). The Intercalary Continental aquifer (CI), which is one of the two principal deep aquifers of the region, is considered a major contributor to the water inflow of Gabes Jeffara, and considered the Tunisian outlet of the North-Western Sahara Aquifer System (NWSAS) (Mamou et al. 2006; Ben Hamouda et al. 2013).

The socioeconomic development of the Gabes region has led to overexploitation of the coastal aquifers, which has induced a drying up of the springs that supplied the oases (Bayrem et al. 2015). Currently, the water extraction rate far exceeds the water recharge rate, resulting in gradual aquifer depletion, degraded water quality and seawater intrusion (Ben Alaya et al. 2014; Agoubi et al. 2013; Werner et al. 2013). Another negative impact is the degradation of oasis ecosystems, which are strongly related to groundwater (Abdedaiem 2016; Mekki et al. 2013).

The objective of this study was to improve the groundwater resources management in the Gabes area, taking into account the needs of socioeconomic activities and the sustainable preservation of coastal oasis ecosystems (Vernoux et al. 2017c). An important part of this study was devoted to developing a numerical flow model of the Jeffara aquifers to be used as a future groundwater management tool considering different scenarios of recharge or exploitation.

\section{Materials and Methods}

\subsection{Study area}

The aquifers of Gabes Jeffara are located in southeastern Tunisia and extend for approximately $3500 \mathrm{~km}^{2}$ (Fig. 1). The study area is limited by El Akarit wadi and Jebel Zimla in the north, the Mediterranean Sea coast in the east, and El Hamma faults and Jebel Aziza to the west. The southern limit consists of Zeuss wadi and the Matmata mountains. Representing part of the Jeffara coastal plain of Tunisia, the region has undergone an arid to semi-arid climate change marked by seasonal contrasting climatic variables. Additionally, this area is influenced by dry/hot and humid air masses coming from the desert and from the Mediterranean Sea, respectively (Kallel 2003). 


\subsection{Geological and hydrogeological setting}

The Gabes Jeffara multilayer aquifer system is formed mainly by sedimentary layers from the Jurassic, Cretaceous and Tertiary ages. The geological model developed as part of this study (Lasseur and Abbes, 2014) includes 18 layers, of which four are considered major aquifers: Mio-Pliocene sands, Senonian limestones (Abid et al. 2012), Turonian limestones (Abid et al. 2011) and the Lower Cretaceous sands. There are three medium aquifers: marly-gypseous formations of the Senonian, upper Barremian sands and upper Jurassic limestones. All these formations constitute the aquifer system of Gabes Jeffara with the exception of the Lower Cretaceous sands (CI) attached to the NWSAS. These CI formations are nevertheless of capital importance because they contribute in an important way to the supply of the deep aquifer of Gabes Jeffara (Trabelsi et al. 2009). Both systems in communication in the El Hamma sector via a fault network (Fig. 2). Above the formations mentioned, there are also Quaternary formations associated with the wadis, and the coastal plain as well as the formations of the continental Quaternary intrarelief. These recent formations constitute the shallow aquifer system of Gabes Jeffara, as opposed to deep aquifers. These different formations were codified by the regional direction for agriculture development (Commissariat Régional au Développement Agricole CRDA) of Gabes according to lithostratigraphy and geographical location (Vernoux et al. 2017b).

\subsection{Data acquisition and processing}

This study, with a multidisciplinary nature, integrates several components from knowledge of groundwater resources, with a three-dimensional (3D) geological model and a groundwater flow model, Integrated Water Resources Management, analysis of water consumption, irrigated agricultural production systems and oasis ecosystems.

All the data processed in this study were integrated into a geographic information system (GIS), including harmonized geological maps, satellite photos and irrigated perimeters.

\subsubsection{Groundwater abstraction and springs}

Groundwater is extracted from shallow and deep wells. The shallow aquifers' global exploitation was deduced from the 5-year frequency publications between 1980 and 2010 and for the three main shallow aquifers (Vernoux et al. 2017b). The total exploitation ranged between 10 million cubic meters (MCM)/y in 1980 and a maximum of 25 MCM/y in 2005 (Fig. 3a). The location of the shallow wells was extracted from the inventory performed in 1995 by Abidi (2004a) (Fig. 3b). The deep wells have been inventoried annually by regional water managers since 1970 . The total exploitation was approximately $50 \mathrm{MCM} / \mathrm{y}$ in 1970 and was more than 100 MCM/y in 2014 (Fig. 3c). This increase is due to an increased number of deep 
wells from approximately 70 in 1970 to more than 300 in recent years (Fig. 3d). In the past, prior to 1970, Gabes Jeffara was known for many springs. The total water flow was approximately $30 \mathrm{MCM} / \mathrm{y}$ in 1970 and is now almost zero (Fig. 3e). This decrease is the result of the increased pumping from wells. The most important springs are those of El Hamma and Gabes (Fig. 3f).

\subsubsection{Groundwater monitoring}

The groundwater level monitoring network is relatively large with approximately 230 shallow and deep wells and piezometers monitored during the period 1970-2014. However, not all the points have continuous monitoring; the measurements are conducted for an average of between 60 and 80 points yearly.

\subsection{Development of the groundwater flow model}

\subsubsection{Modeling tool and Methodology}

The groundwater flow model was implemented with the MODFLOW-2000 simulator, a quasi-3D finitedifference groundwater flow model (Harbaugh et al. 2000). The package Processing Modflow 8 was used for pre- and post-processing (Simcore Software 2012). MODFLOW resolves the flow equation (Eq. 1) in steady and transient states for confined/unconfined multilayered aquifers.

$$
\frac{\partial}{\partial x}\left(e_{i} K_{x, i} \frac{\partial h_{i}}{\partial x}\right)+\frac{\partial}{\partial y}\left(e_{i} K_{y, i} \frac{\partial h_{i}}{\partial y}\right)+\mathrm{VL}_{i, i+1}\left(h_{i+1}-h_{i}\right)+\mathrm{VL}_{i, i-1}\left(h_{i-1}-h_{i}\right)=S_{i} \frac{\partial h_{i}}{\partial t}+q_{i}
$$

where: $h_{i}, h_{i+1}$, and $h_{i-1}$ indicate the hydraulic heads [L] of layers $i, i+1$ and $i-1$, respectively; $K_{x, i}$ and $K_{y, i}$ the horizontal hydraulic conductivities $[\mathrm{L} / \mathrm{T}]$ in $x$ and $y$ directions, respectively; $e_{i}$ the saturated thickness; $\mathrm{VL}_{i, i+1}$ and $\mathrm{VL}_{i, i-1}$ the vertical leakance coefficients [1/T]; $S_{i}$ the storage coefficient [-]; and $q_{i}$ the source/sink term $[\mathrm{L} / \mathrm{T}]$.

The modeling domain is based on the hydrogeological studies performed by several authors (Barthelemy and Zammouri 2015). In fact, the complexity of the Gabes Jeffara aquifers was first simplified to set up the conceptual model and boundary conditions. All collected data were analyzed and synthesized to set up the model input. The model calibration was performed in steady and transient states by referring to groundwater level monitoring and spring flow measurements for the period 1970-2014. Once calibrated, the model could be used to simulate the groundwater flow in future decades according to several scenarios of recharge and exploitation.

\subsubsection{Conceptual model}

The geological model enabled update of the complex structural scheme of the Gabes multilayers known as the Gabes Jeffara aquifer system. This model allowed for the characterization of several aquifers and aquitards and of the possible hydrodynamic relationship between them (Fig. 4). Aquifer 2 is mainly present 
in the northern part of the Jeffara, aquifer 3 is present in the south, and EL Hamma-Chenchou, Oglet Merteba, Matmatas and aquifer 5 are in the Zeuss-Koutine area. The hydrodynamic analyses performed by Vernoux et al. (2017b) confirmed a significant horizontal hydraulic communications between these aquifers. Spatially, these aquifers are connected with the Quaternary aquifer (Aquifer 1) by aquitards. These analyses allowed for consideration of them as a single layer in the model. This geological model also shows the main faults, the distribution of hot springs in the El Hamma region and the relations between the Jeffara Plain and the NWSAS through the CI (Aquifer 3).

The conceptual model was outlined considering the geological setting and the analyses, as presented above. Three main aquifers were identified (Fig. 5). The first aquifer corresponds to the phreatic aquifer contained in the Quaternary formations, exploited by shallow wells. The second aquifer groups the many deep layers recognized in Gabes Jeffara, which are exploited by deep wells: Gabes North and South, El Hamma, Chenchou, Oglet Merteba, Matmatas and Zeuss Koutine (ZK). The last aquifer represents the CI, which is not exploited in the study area but is used to simulate the groundwater flow between Jeffara and the CI. Vertical communication can occur between the layers through fractures in aquitards. The aquifers are recharged directly by rainfall infiltration in permeable outcrops or by runoff water and by the water inflow from the CI. The natural water outlets come from springs and wadi drainage, evapotranspiration from the water table and from the sea.

\subsubsection{Grid design and boundary conditions}

The model domain overlays a regular grid of 171 rows and 212 columns with 500-m square cells (Jarraya Horriche 2017). The aquifers are conceptualized of three layers with approximately 32,000 active cells. Vertical leakance between the aquifers occurs through the aquitards and mainly along the fractures. Boundary conditions were fixed according to the conceptual model as follows:

- Recharge was applied to all of the top active cells by rainfall or runoff water infiltration.

- Pumping from shallow or deep aquifers was introduced as outflow fixed fluxes with respect to the first and second layers.

- The groundwater level was fixed to zero along the coastline for the phreatic aquifer to represent the sea boundary condition. A variable head was fixed in the northwestern limit of the CI aquifer to represent the inflow from the NWSAS.

- No flux was fixed in the other boundaries except those indicated above.

- The drainage by wadis and springs $\left(Q_{d}\right)$ was represented by drainage conditions in respect of the first and second layers. It is simulated according to Eq. 2.

$$
Q_{d}=C_{d}(h-d)
$$

Where: $h$ is the hydraulic head in the cell [L], $d$ the drain elevation [L], and $C_{d}$ the drain hydraulic conductance $\left[\mathrm{L}^{2} / \mathrm{T}\right]$. 
- An evapotranspiration condition was introduced in the phreatic aquifer to simulate the outflow from the water table. Evapotranspiration (ET) is simulated according to Eq. 3.

$$
\mathrm{ET}=\mathrm{ET}_{\max }\left[\frac{h-(Z-p)}{p}\right]
$$

Where: $\mathrm{ET}_{\max }$ indicates the maximum evapotranspiration $[\mathrm{L} / \mathrm{T}], h$ the hydraulic head $[\mathrm{L}], Z$ the ground level $[\mathrm{L}]$, and $p[\mathrm{~L}]$ the water table depth beyond which ET is null.

\subsubsection{Groundwater recharge}

Gabes Jeffara is mainly recharged by rainfall infiltration in permeable outcrops or by runoff water. The latter was assessed by referring to the hydrologic study performed at the level of Gabes Jeffara watersheds (Vernoux et al. 2017b). The rainfall infiltration in permeable outcrops was deduced from an overall estimation of infiltration capacity according to the geological formations and from the field knowledge of hydrogeologists. The overall recharge was computed to an average of $16.4 \mathrm{MCM} / \mathrm{y}$. In the groundwater flow model, this recharge was distributed within the watersheds using the water accumulation ratio deduced from the Digital Elevation Model (DEM) (Jarraya Horriche 2017). The runoff recharge in a cell was calculated according to Eq. 4. Thus, runoff water was mainly recharged in the watercourse network of each watershed. In addition to the runoff water infiltration, some areas were recognized as highly permeable outcrops favorable for direct rainfall infiltration such as the areas of Matmatas, El Hamma-Chenchou and Oudhref.

$$
R(i)=\frac{A(i)}{\sum_{1}^{N} A(i)} \mathrm{RW}
$$

Where: RW is the total runoff recharge in the watershed $[\mathrm{L} / \mathrm{T}]$ and $A(i)$ the surface accumulation water in a cell within the watershed [-] which is calculated by GIS using the DEM.

\subsubsection{NWSAS groundwater inflow}

Groundwater inflow from the NWSAS occurs through the CI aquifer in the north-western limit which represents a principal inflow water source of the Jeffara aquifers. This inflow, known as the "Tunisian outlet", goes by vertical leakance to the Jeffara aquifers through several faults mainly in the El HammaChenchou areas. According to previous studies, this inflow was assessed to $3.1 \mathrm{~m}^{3} / \mathrm{s}$ (OSS, 2003) and 3.6 $\mathrm{m}^{3} / \mathrm{s}$ (Besbes et al., 2005) in 1950. This last study assessed the inflow to $1.4 \mathrm{~m}^{3} / \mathrm{s}$ in 2000 . In the present groundwater flow modeling, variable heads were fixed in the northwestern limit of the CI aquifer by referring to head measurements in the CI near this limit. Head values ranged between 140 and $155 \mathrm{~m}$ in 1970 and decreased to about 60-72 $\mathrm{m}$ in 2014. The same tendency of measured heads was used in the fixed heads limit.

\subsubsection{Hydrodynamic parameters}

The Gabes Jeffara aquifer has been investigated by many researchers since 1970, which allowed an overall assessment of the hydraulic transmissivity and storage coefficient in many regions and for some aquifers 

also allowed the measurement of these parameters. Abidi (2004b) summarized these studies and adopted the average values that were used for the first calibration of the model (Table 1).

When referring to the groundwater flow modeling conducted for the whole Jeffara aquifer in Tunisia and Libya (Besbes et al. 2005), the calibrated transmissivity is approximately $4 \times 10^{-3} \mathrm{~m}^{2} / \mathrm{s}$ for the phreatic aquifer and ranges between 1 and $2 \times 10^{-2} \mathrm{~m}^{2} / \mathrm{s}$ for the deep aquifer. The storage coefficient was calibrated to 0.15 for the phreatic aquifer and 0.03 for the deep aquifer.

Table 1. Average measured transmissivity and storage coefficient

\begin{tabular}{|l|c|c|}
\hline Aquifer & Transmissivity $\left(\mathbf{m}^{2} / \mathbf{s}\right)$ & Storage Coefficient \\
\cline { 1 - 2 } Northern Gabes (Sand layer) & $10 \times 10^{-3}$ & $10^{-6}-5 \times 10^{-4}$ \\
\cline { 1 - 2 } Northern Gabes (Limestone layer) & $30 \times 10^{-3}$ & $3 \times 10^{-5}-2 \times 10^{-4}$ \\
\hline El Hamma-Chenchou & $40 \times 10^{-3}$ & $3 \times 10^{-5}-10^{-2}$ \\
\hline Southern Gabes & $40 \times 10^{-3}$ & - \\
\hline Oglet Merteba & $5 \times 10^{-3}$ & $2 \times 10^{-2}-9 \times 10^{-2}$ \\
\hline Phreatic aquifer & $9 \times 10^{-2}$ & \\
\hline
\end{tabular}

\subsection{Calibration and validation of the groundwater flow model}

The model was first calibrated in steady state for 1970. During this period, the pumping rates, spring flows and groundwater levels remained relatively stable, confirming the quasi-equilibrium of the groundwater

Calibration was performed from groundwater levels measured in more than 200 wells and piezometers and

Finally, the model was validated for the period 1991-2014 by extending the transient state until 2014 Validation was performed using other groundwater level measurements and spring flow for this period. 
The analysis of current and future water consumption was carried out with existing data, the processing of satellite images, and farmer surveys (Vernoux et al. 2017a). Processed satellite images were used to assess the total areas of the different irrigated areas, the areas actually irrigated and the volumes of water consumed, when these data were not enabled.

Current water requirements were estimated at $125 \mathrm{Mm}^{3}$ in 2014 (baseline year), of which $82 \%$ was for the irrigated perimeters for a total irrigated area of more than 14,000 ha. Non-agricultural water requirements the industrial and tourism sectors were low and represented only $7 \%$ of total requirements.

The second step of the process consisted of identifying the main factors of changes that could influence water needs in the future and then describing their evolution trends by 2040 . Three scenarios were predefined for the future (Fig. 6). The first scenario A (trend) is based on the continuation of past trends (continued urbanization of oases, increase in the area of private irrigated areas, etc.). The second scenario $\mathrm{B}$ (pessimistic) assumes an aggravation of past trends relative to scenario A. The third scenario C (optimistic) assumes that current and future pressures on water resources will be lower, compared to scenario A.

Future irrigation water needs by 2040 are estimated at a best-case scenario of $215 \mathrm{MCM} / \mathrm{y}$ (scenario C) and at a worst-case scenario of $517 \mathrm{MCM} / \mathrm{y}$ (scenario B). Considering the assumptions in the trend scenario, these needs would be $286 \mathrm{MCM} / \mathrm{y}$ in 2040.

Studying the functional levels of oasis ecosystems enabled definition of the links between the ecosystems and the groundwater of the Tunisian Jeffara aquifers and facilitated the proposal of a protocol for monitoring these links, through a number of indicators and predefined parameters (Abdedaiem 2016).

Finally, an Integrated Water Resources Management (IWRM) assessment was carried out, with the main objective of defining water demand scenarios combined with scenarios of decreased groundwater withdrawal, reinforced groundwater recharge and use of alternative water resources (Hamza 2017). These scenarios were tested with the hydrodynamic model to see their impact on groundwater levels and spring flow rates.

During modeling simulations, rainfall and runoff recharge were maintained constant and equal to the average value of the transient period (1970-2014). The fixed head boundary for the phreatic aquifer was the same as for the steady and transient states. For the NWSAS-CI boundary, variable fixed heads were considered by extrapolating the tendency of measured heads during the transient state for the simulation period, as a first step. In a second step, variable fixed fluxes were applied by extrapolating the tendency of calculated values by the model. All the parameters such as transmissivity, vertical leakance, storage coefficient, drainage and evapotranspiration-related parameters, were maintained the same as for the transient state. Initial condition corresponded to the hydraulic head calculated in 2014. 


\section{Results and Discussion}

\subsection{Model performance assessment}

The assessment of the model calibration was first based on the comparison of simulated and measured groundwater levels. The mean square error (MSE) for the steady state calibration was equal to $18 \mathrm{~m}^{2}$ for the shallow aquifer and $21 \mathrm{~m}^{2}$ for the deep aquifer (Figs. $7 \mathrm{~b}$ and $7 \mathrm{~d}$ ). The piezometric maps simulated by the model confirm the hydrodynamic functioning of the groundwater and the drainage of the groundwater downstream of the wadis, at the level of the wetlands and the springs (Figs. $7 \mathrm{a}$ and $7 \mathrm{c}$ ). The variation of the simulated heads and spring flows are shown to be close to the measured values for most piezometers and springs (Figs. 8 and 9).

The water balance computed in steady and transient states shows that the total inflow was approximately $4.9 \mathrm{~m}^{3} / \mathrm{s}$ in 1970, shared between rainfall recharge and inflow from the Intercalary Continental (CI) (Tab. 2). During this period, the well pumping rate was $1.9 \mathrm{~m}^{3} / \mathrm{s}$ and computed drainage flow mainly from springs was $1 \mathrm{~m}^{3} / \mathrm{s}$. The remaining outflow was the evapotranspiration from the water table in the wetland areas. In 2014, the CI inflow decreased to $0.7 \mathrm{~m}^{3} / \mathrm{s}$ because of the decrease in the CI hydraulic heads in the northwestern boundary limits. Consequently, a depletion of the springs and an increase of the well pumping rate to $3.9 \mathrm{~m}^{3} / \mathrm{s}$ were noticed. This situation induced a decrease in hydraulic heads and evapotranspiration flux from the water table. At the same time, a decrease in wetland areas was observed, compared to the 1970 scenario. The overall water balance showed a contribution of $3.2 \mathrm{~m}^{3} / \mathrm{s}$ from the groundwater storage.

The model results confirm those of previous studies, especially the groundwater inflow from the CI aquifer. The inflow was computed as $3.1 \mathrm{~m}^{3} / \mathrm{s}$ and $3.5 \mathrm{~m}^{3} / \mathrm{s}$ in 1950 according to OSS (2003) and Besbes et al. (2005), respectively. By 2000, this inflow had decreased to $1.5 \mathrm{~m}^{3} / \mathrm{s}$ and $1.4 \mathrm{~m}^{3} / \mathrm{s}$ in the same studies.

Table 2 Water balances simulated by the model

\begin{tabular}{|c|c|c|c|c|}
\hline \multirow{2}{*}{ Parameter } & \multicolumn{2}{|c|}{$\mathbf{1 9 7 0}$} & \multicolumn{2}{c|}{$\mathbf{2 0 1 4}$} \\
\cline { 2 - 5 } & $\begin{array}{c}\text { Inflow } \\
\left(\mathbf{m}^{\mathbf{3}} / \mathbf{s}\right)\end{array}$ & $\begin{array}{c}\text { Outflow } \\
\left(\mathbf{m}^{\mathbf{3}} / \mathbf{s}\right)\end{array}$ & $\begin{array}{c}\text { Inflow } \\
\left(\mathbf{m}^{\mathbf{3}} / \mathbf{s}\right)\end{array}$ & $\begin{array}{c}\text { Outflow } \\
\left(\mathbf{m}^{\mathbf{3}} / \mathbf{s}\right)\end{array}$ \\
\hline Inflow from CI & 2.93 & - & 0.74 & - \\
\hline Exchange with the sea & - & 0.19 & 0.00 & 0.13 \\
\hline Pumping total: & - & 1.88 & - & 3.93 \\
\hline Pumping from shallow wells & - & 0.20 & - & 0.69 \\
\hline Pumping from deep wells & - & 1.68 & - & 3.24 \\
\hline Drainage total: & - & 1.00 & - & 0.04 \\
\hline
\end{tabular}




\begin{tabular}{|r|c|c|c|c|}
\hline Drainage from wadis & - & 0.04 & - & 0.02 \\
\hline Drainage from springs & - & 0.96 & - & 0.02 \\
\hline Recharge & 1.96 & - & 1.14 & - \\
\hline $\begin{array}{l}\text { Evapotranspiration from the water } \\
\text { table }\end{array}$ & - & 1.82 & - & 0.99 \\
\hline $\begin{array}{r}\text { Groundwater storage } \\
\text { TOTAL }\end{array}$ & - & - & 3.20 & - \\
\hline
\end{tabular}

\subsection{Simulation of groundwater management scenarios}

The calibrated model was used to simulate the impact of groundwater exploitation in the future according to several management scenarios by referring to the water demand of the Gabes region (Bouzit et al., 2017). Six scenarios were tested with the model over the period 2015-2040 (Jarraya Horriche 2017; Chaif et al. 2017). For all simulations, fixed head was kept the same along the coast for the phreatic aquifer. For rainfall and runoff recharge, constant values were considered on the base of an average rainfall for 1970-2040. Parameters for evapotranspiration and drainage boundary conditions were the same as those of the transient state.

For scenario 1, the pumping rates were kept constant throughout the period. The inflow from the CI (the Tunisian outlet) will be equal to $0.15 \mathrm{~m}^{3} / \mathrm{s}$ in 2040 . The overall water balance deficit will be on the order of $2 \mathrm{~m}^{3} / \mathrm{s}$. The groundwater level will be affected by a drawdown ranging between $5 \mathrm{~m}$ and $15 \mathrm{~m}$, mainly near the spring areas of El Hamma. Also noted is a shrinkage of the salty wetlands (sebkhas) following the decrease in evapotranspiration from the water table. For scenario 2, a linear increase in the pumping rates of all the deep wells was considered, while keeping their number constant. Thus, the total pumping rate will be equal to $5.2 \mathrm{~m}^{3} / \mathrm{s}$ in 2040 . The results of this simulation show that water salinization could take place after the higher groundwater level declines, and consequently, the inversion of the hydraulic gradient occurs, mainly in northern Gabes. The overall areas will be affected by additional decreases in groundwater levels, drainage and spring flows and evapotranspiration from the water table, compared to scenario 1 . The water balance deficit will be equal to $3 \mathrm{~m}^{3} / \mathrm{s}$ in 2040, and the drainage flow through wadis and springs will be almost zero. The inflow from the CI will decrease to $0.37 \mathrm{~m}^{3} / \mathrm{s}$ in 2040 following the piezometric drops in El Hamma.

Scenarios 3 and 4 are based on water demand scenarios, as defined in the socioeconomic analysis (scenarios A and $\mathrm{C}$ in Fig. 6) without water resource management measures, while scenarios 5 and 6 are based on the same water demand scenarios but with water resource management measures (Hamza, 2017). The management measures tested in scenarios 5 and 6 can be grouped into three classes: reducing withdrawals, enhancing recharge, and using alternative water resources, in particular seawater desalination. These measures have been spatialized according to their nature, the targeted water tables and the concerned administrative delegations.

For scenario 3, the total pumping rates will be equal to $8.9 \mathrm{~m}^{3} / \mathrm{s}$ in 2040 , inducing a more critical situation for the water balance (Tab. 3) and for groundwater level drawdown (Fig. 10a). Therefore, we considered 
scenario 6 with water resources management measures, which (i) limit the evolution of irrigated areas, (ii) reduce abstractions by better valorization of pumped water, both by promoting water-saving crops and by improving the efficiency of distribution networks, (iii) reinforce recharge and (iv) use unconventional water resources (desalination, for example). These measures can reduce groundwater abstraction by 2 to $3 \mathrm{~m}^{3} / \mathrm{s}$ and reach in 2040 the same total pumping rate as in 2014 (Tab. 2). The results of this simulation show that the water balance in 2040 will be similar to that of 2014 and that the groundwater level drawdown will be reduced (Fig. 10b).

Table 3 Water balances simulated by the model in 2040 for scenarios 3 and 6

\begin{tabular}{|c|c|c|c|c|}
\hline \multirow{2}{*}{ Parameter } & \multicolumn{2}{|c|}{$\begin{array}{c}\mathbf{2 0 4 0} \text { - Scenario 3 } \\
\text { (water demand scenario A } \\
\text { without water resource } \\
\text { management measures) }\end{array}$} & $\begin{array}{c}\text { 2040 - Scenario 6 } \\
\text { (water demand scenario C } \\
\text { with water resource } \\
\text { management measures) }\end{array}$ \\
\cline { 2 - 5 } & $\begin{array}{c}\text { Inflow } \\
\left(\mathrm{m}^{3} / \mathrm{s}\right)\end{array}$ & $\begin{array}{c}\text { Outflow } \\
\left(\mathrm{m}^{3} / \mathrm{s}\right)\end{array}$ & $\begin{array}{c}\text { Inflow } \\
\left(\mathrm{m}^{3} / \mathrm{s}\right)\end{array}$ & $\begin{array}{c}\text { Outflow } \\
\left(\mathrm{m}^{3} / \mathrm{s}\right)\end{array}$ \\
\hline Inflow from CI & 0.32 & - & 0.32 & - \\
\hline Exchange with the sea & 0.08 & 0.04 & 0.003 & 0.169 \\
\hline Pumping total: & - & 8.91 & - & 4.00 \\
\hline Pumping from shallow wells & - & 0.876 & - & 0.08 \\
\hline Pumping from deep wells & - & 8.037 & - & 3.92 \\
\hline Drainage from wadis & - & 0.002 & - & 0.02 \\
\hline Drainage from springs & - & 0.002 & - & 0.020 \\
\hline Recharge & 2.47 & - & - & 0.006 \\
\hline $\begin{array}{l}\text { Evapotranspiration from the water } \\
\text { table }\end{array}$ & - & 0.000 & 2.47 & - \\
\hline Groundwater storage & 6.45 & - & 2.83 & - \\
\hline & $\mathbf{9 . 3 2}$ & $\mathbf{9 . 3 2}$ & $\mathbf{5 . 6 3}$ & $\mathbf{5 . 6 3}$ \\
\hline
\end{tabular}

\section{Conclusions}

The Gabes Jeffara aquifer system, in southern Tunisia, is very important for the regional water supply. Increasing water demand, mainly for irrigation, has led to a need for better management of this crucial resource to prevent groundwater depletion and deteriorating effects, such as saltwater intrusion from over pumping, in this coastal region. A groundwater flow model was developed to simulate different scenarios of water demand and to be used as a tool for groundwater resource control and for help in planning further exploitation of the system, including the use of nonconventional water resources.

The groundwater flow model is based on a 3D geological model (Lasseur and Abbes 2014) and approximately 50 years of monitoring data: withdrawals, piezometric levels, and spring water flows. The model was calibrated in steady state with reference to the piezometric measurements measured in 1970. The piezometric maps plotted by the model confirm the hydrodynamic functioning of the groundwater and the drainage of the groundwater downstream of the wadis, at the level of the wetlands and springs. The model was calibrated in transient state for the period 1972-2014, using records from more than 200 wells 
and piezometers. The model confirms the importance of the groundwater inflow from the Continental Intercalary (Besbes et al. 2005) and its decline (from $3 \mathrm{~m}^{3} / \mathrm{s}$ in 1970 to $0.75 \mathrm{~m}^{3} / \mathrm{s}$ in 2014).

The tested scenarios show that the decline in groundwater levels of the Jeffara aquifers is likely to continue, with the induced effects of reduced exploitable resources, deteriorated groundwater quality and increased operating costs. Even with an unrealistic assumption of maintaining water withdrawals at their 2014 level (Scenario 1), water table decline will continue, under the double effect of withdrawals exceeding aquifer recharge and the inexorable decline of the Continental Intercalary water supply. Nevertheless, the simultaneous implementation of management measures, with the aim of improving the use of existing resources, reinforcing recharge and bringing new resources, can, however, enable a very significant reduction in the decline of groundwater levels.

Acknowledgements The authors gratefully acknowledge FFEM (French Facility for Global Environment) and AFD (French Agency for Development) for financial support and CRDA (Regional Commissariat for Agricultural Development) of Gabes for technical support.

\section{References}

Abdedaiem S. (2016) Gestion des Aquifères côtiers des Oasis de Gabès - Analyse des écosystèmes oasiens de Gabès et de leurs relations avec les aquifères [Management of coastal aquifers in Gabes Oases - Analysis of oasis ecosystems in Gabes and their relationship with aquifers]. Report BRGM/RC-67032-FR, 85 p.

Abid K, Zouari K., Dulinski M., Chkir N., Abidi B. (2011) Hydrologic and geologic factors controlling groundwater geochemistry in the Turonian aquifer (southern Tunisia). Hydrogeology Journal 19, 415-427. https://doi.org/10.1007/s10040-010-0668-Z

Abid K., Hadj Ammar F., Chkir N., Zouari K. (2012) Relationship between Senonian and deep aquifers in Southern Tunisia, Quaternary International, Volume 257, 2012, Pages 13-26, ISSN 1040-6182,

Abidi B. (2004a) Etude des nappes phréatiques de la Jeffara de Gabès [Study of the shallow groundwater of the Gabes Jeffara]. Internal report. CRDA de Gabès.

Abidi B. (2004b) Caractéristiques hydrodynamiques et géochimiques de la Jeffara de Gabès [Hydrodynamic and geochemical characteristics of the Gabes Jeffara]. Internal report. CRDA de Gabès.

Agoubi B., Kharroubi A., Abichou t., Abida H. (2013) Hydrochemical and geoelectrical investigation of Marine Jeffara Aquifer, southeastern Tunisia. Applied Water Science, 3(2): 415-429, https://doi.org/ 10.1007/s13201-013-0091-4

Barthélemy Y., Zammouri M. (2015) - Projet de Gestion des Aquifères côtiers des Oasis de Gabès -Synthèse des modèles existants et préfiguration du modèle hydrogéologique conceptuel [Management of coastal aquifers in Gabes Oases - Synthesis of existing models and prefiguration of the conceptual hydrogeological model]. report BRGM/RC64551-FR, $182 \mathrm{p}$

Bayrem N., Moussa M., Rejeb H. (2015) The water Resources Challenges in Gabes Oasis. Int. Res.J. Earth Sci, 3(3) : 15-19 
Ben Alaya M., Saidi S, Zemni T, Zargouni F (2013) Suitability assessment of deep groundwater for drinking and irrigation use in the Jeffara aquifers (Northern Gabes, south-eastern Tunisia). Environ Earth Sci. https://doi.org/10.1007/s12665-013-2729-9

Ben Hamouda M., Mamou A., Bejaoui J., Froehlich K. (2013) Hydrochemical and Isotopic Study of Groundwater in the North Djeffara Aquifer, Gulf of Gabès, Southern Tunisia, International Journal of Geosciences, 4(8A):1-10. https://doi.org/10.4236/ijg.2013.48A001

Besbes, M., Bouhlila R., Pallas, P., Pizzi, G., Ayoub, A., Babasy, M., El Barouni, S. et Horriche, F. (2005) Etude sur modèles mathématiques de la Jeffara tuniso-libyenne [Study on mathematical models of Tunisian-Libyan Jeffara]. OSS report.

Bouzit M., J.F. Vernoux, M. Sghair et M. Abdeadhim (2017) Projet de gestion des aquifères côtiers des oasis de Gabès - Analyse socio-économique et évolution future des besoins en eau du gouvernorat de Gabès [Management of coastal aquifers in Gabes Oases - Socio-economic analysis and future evolution of the water needs of Gabes governorate]. report. BRGM/RC-66708-FR, $68 \mathrm{p}$

Chaif H., Vernoux J.F., Jarraya Horriche F., Barthélemy Y. (2017) Gestion des Aquifères côtiers des Oasis de Gabès - Modélisation hydrodynamique : Scénarios prévisionnels basés sur des projections d'évolution de la demande en eau, avec et sans mesures de gestion [Management of coastal aquifers in Gabes Oasis - Hydrodynamic model : Previsionnel scenarios based on projected evolution of water demand, with and without management actions]. Report BRGM/RC-67186-FR, 87 p.

Hamza M. (2017) Projet de gestion des aquifères côtiers des oasis de Gabès - Gestion intégrée des ressources en eau et des écosystèmes associés [Management of coastal aquifers in Gabes Oases - Integrated management of water resources and associated ecosystems]. Report BRGM/RC-66280-FR, 243 pages

Harbaugh AW, Banta ER, Hill MC, McDonald MG (2000) MODFLOW-2000, The U.S. Geological Survey modular ground-water model: user guide to modularization concepts and the ground-water flow process. US Geological Survey, Reston, $121 \mathrm{p}$

Jarraya Horriche F. (2017) Gestion des Aquifères côtiers des Oasis de Gabès - Modèle hydrodynamique de la Djeffara de Gabès [Management of coastal aquifers in Gabes Oasis - Hydrodynamic model of Gabes Djeffara]. Report BRGM/RC-67031-FR, 139 p.

Kallel R (2003) Hydrologie de la Jeffara tunisienne [Hydrology of the Tunisian Jeffara. Internal report. CRDA of Gabes

Lasseur E., Abbes C. (2014) Projet de gestion des aquifères côtiers des oasis de Gabès - Modélisation géologique 3D de la Jeffara de Gabès [Management of coastal aquifers in Gabes Oases - 3D geological modeling of the Gabes Jeffara. Report BRGM/RC-64626-FR, 94 p.

Lezzaik K, Milewski A (2018) A quantitative assessment of groundwater resources in the Middle East and North Africa region. Hydrogeol J 26:251-266. https://doi.org/10.1007/s10040-017-1646-5

Mamou A., Besbes M., Abdous B., Latrech D.J. and Fezzani C. (2006) North Western Sahara Aquifer System (NWSAS), in Non-Renewable Groundwater Resources, a guidebook on socially-stainable management for water- 
policy maker, edited by S. Foster and D.P. Loucks, UNESCO, 68-74 https://fr.ircwash.org/sites/default/files/Foster2006-Nonrenewable.pdf\#page=62

Mekki I, Jacob F, Marlet S, Ghazouani W (2013) Management of groundwater resources in relation to oasis sustainability: the case of the Nefzawa region in Tunisia. J Environ Manage 121:142-151. https://doi.org/10.1016/j.jenvman.2013.02.041

Mekrazi A (1975) Contribution à l'étude géologique et hydrogéologique de la région de Gabès Nord. Thèse de Doctorat ès Sciences Géologiques, [Contribution to the hydrogeological Study of the Gabes Region North], 3rd Cycle Thesis, University of Bordeaux I,, 230 p.

Observatoire du Sahara et du Sahel (OSS) (2003) Système Aquifère du Sahara Septentrional: Modèle mathématique, vol. IV [Aquifer System of the Northern Sahara: Mathematical model, vol. IV]. http://www.ossonline.org/fr/syst\%C3\%A8me-aquif\%C3\%A8re-du-sahara-septentrional-mod\%C3\%A8le-math\%C3\%A9matique$\underline{\text { volume-iv }}$

Rouatbi R. (1967) Contribution à l'étude hydrogéologique du Karst enterré de Gabès Sud. (Contribution to the Study of Hydrogeological Buried Karst of South Gabes), PhD Thesis, University of Montpellier, 235 p.

Simcore Software (2012) Processing Modflow. An Integrated Modeling Environment for the Simulation of Groundwater Flow, Transport and Reactive Processes. User's guide. http://www.simcore.com/

Trabelsi, R., Kacem, A. , Zouari, K., Rozanski, K. (2009) Quantifying regional groundwater flow between Continental Intercalaire and Djeffara aquifers in southern Tunisia using isotope methods. Environmental Geology 58(1): 171-183. https://doi.org/10.1007/s00254-008-1503-X

UNESCO (1972) Etude des ressources en eau du Sahara septentrional. Projet ERESS [Study of the water resources of the northern Sahara. ERESS project]. https://unesdoc.unesco.org/ark:/48223/pf0000001564

Vernoux J.F., Bouzit M., Desprats J.F., Ben Salah M., Sghair M., Abdeadhim M. (2017a) Gestion des Aquifères côtiers des Oasis de Gabès - Analyse des systèmes de production agricole irriguée [Management of coastal aquifers in Gabes Oases - Analysis of irrigated agricultural production systems]. Report BRGM/RC-65740-FR, 77 p.

Vernoux J.F., Machard de Gramont H., Barthélemy Y., Croiset N., Gourcy L., Stollsteiner P. (2017b) Gestion des Aquifères côtiers des Oasis de Gabès - Synthèse hydrogéologique [Management of coastal aquifers in Gabes Oases Hydrogeological synthesis]. Report BRGM/RC-64953-FR, 200 p.

Vernoux J.F., Horriche F., Ghoudi R., Abdedaiem S., Hamza M. (2017c) Management of Gabes Jeffara aquifers in relation with oasien ecosystems. In Recent Advances in Environmental Science from the Euro-Mediterranean and Surrounding Regions: Proceedings of Euro-Mediterranean Conference for Environmental Integration (EMCEI-1), Tunisia 2017, p. 599-602.

Werner AD, Simmons CT (2009) Impact of sea-level rise on sea water intrusion in coastal aquifers. Ground Water 47:197-204. https://doi.org/10.1111/j.1745-6584.2008.00535x 


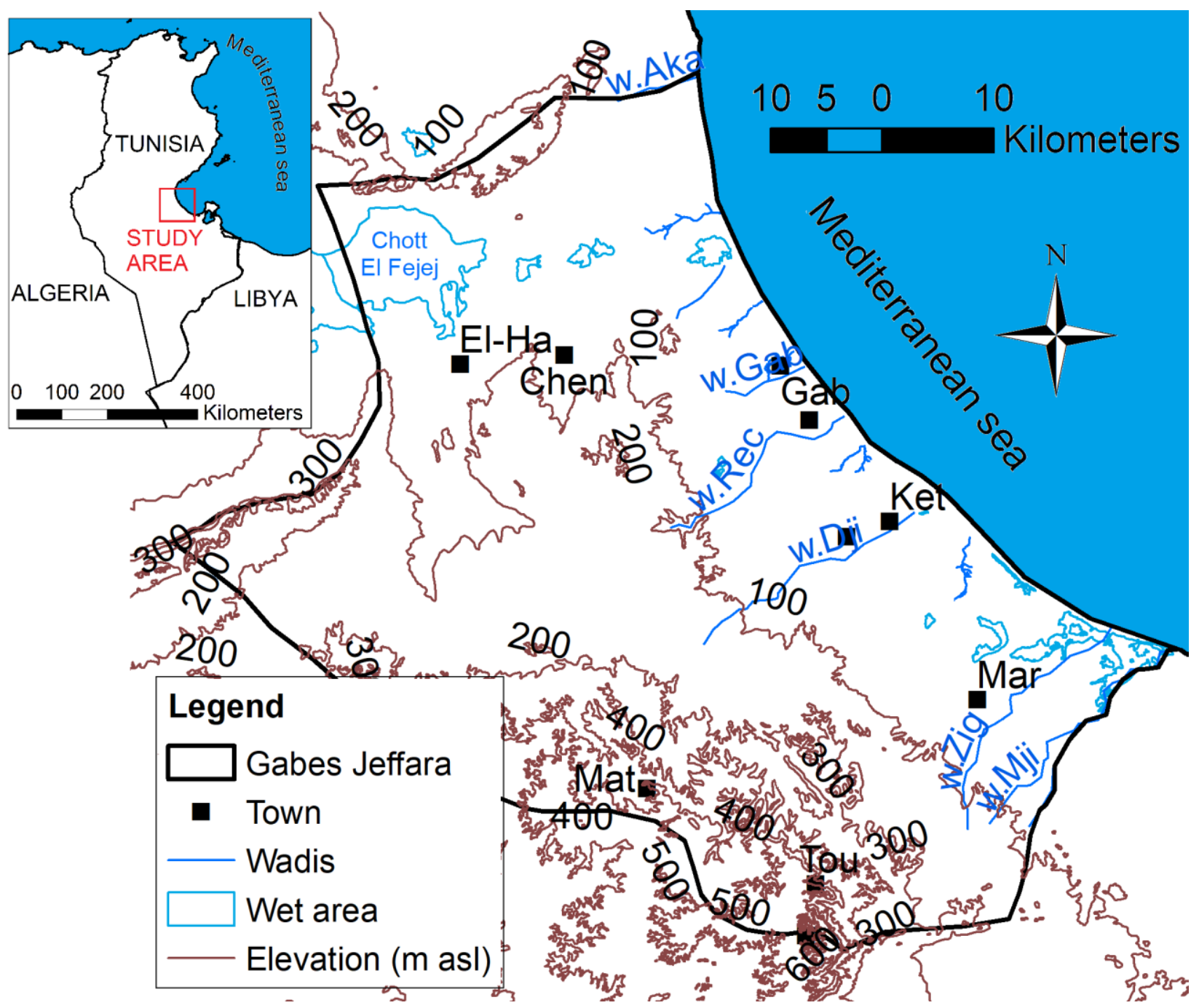

Fig. 1 Location map of the study area, in the governorate of Gabes. Towns: El Hamma (El-Ha); Chenchou (Chen); Gabes (Gab); Mareth (Mar); Kettatna (Ket); Toujane (Tou); Matmata (Mat). Wadis (w.): Akarit (Aka); Gabes 
(a)

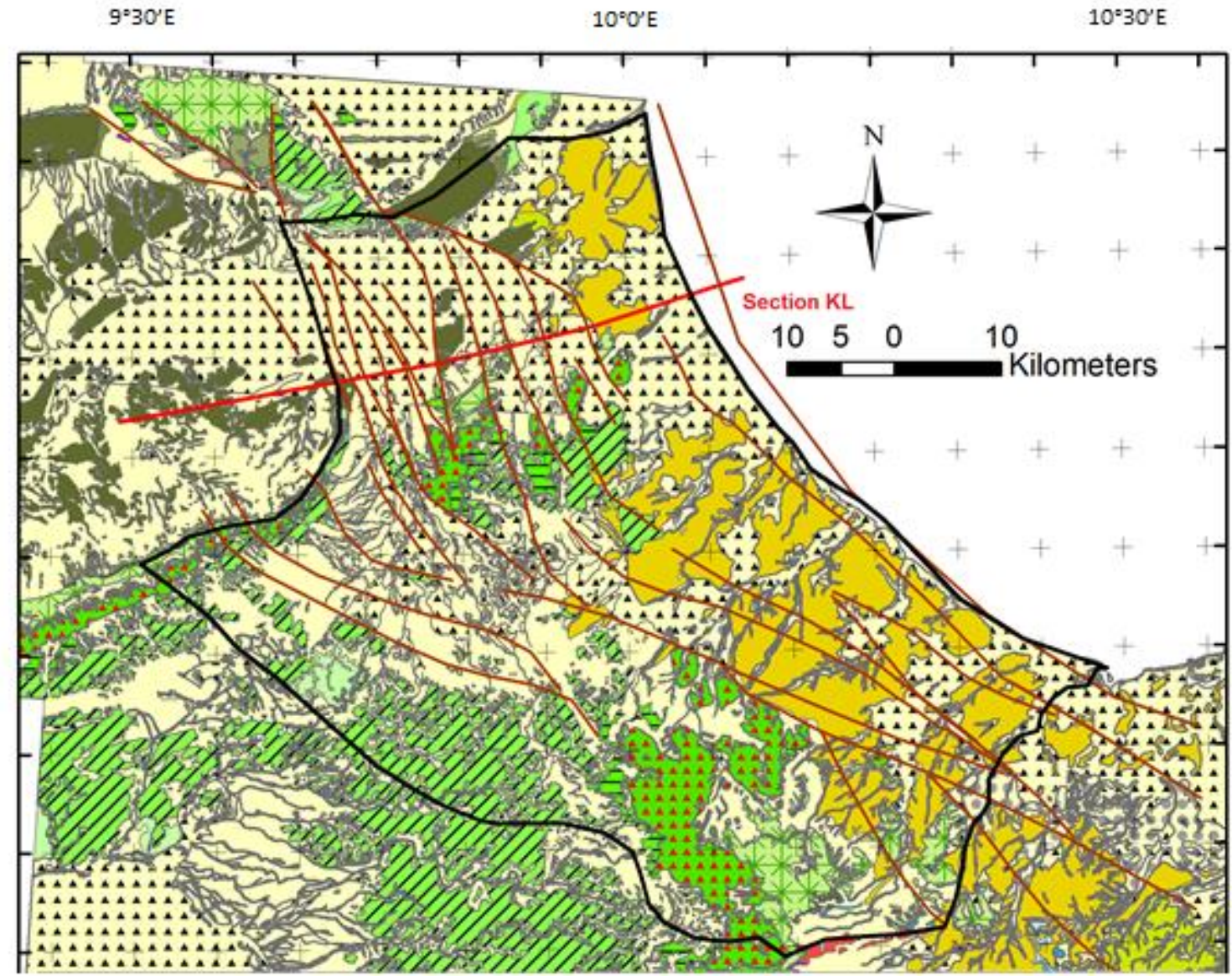

\section{Legend}

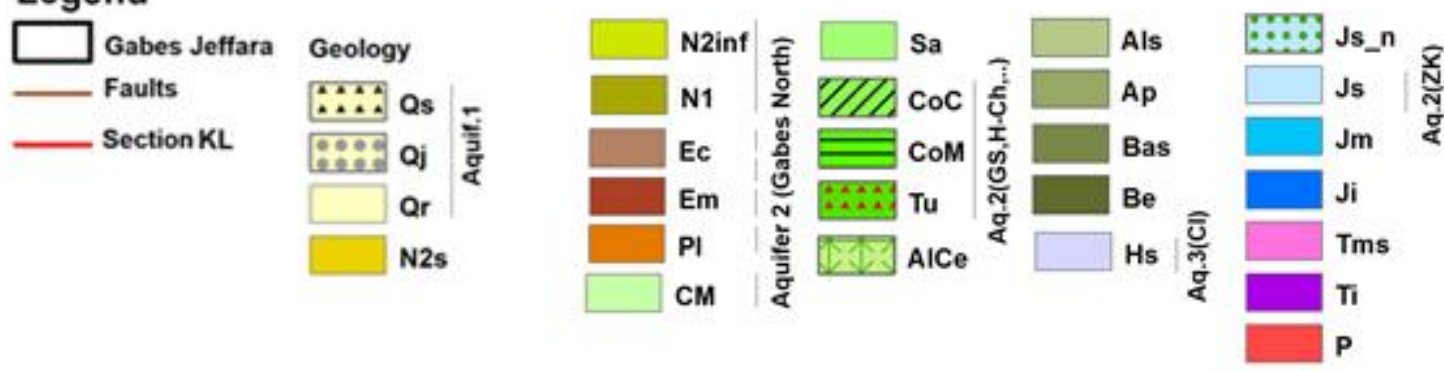

(b)

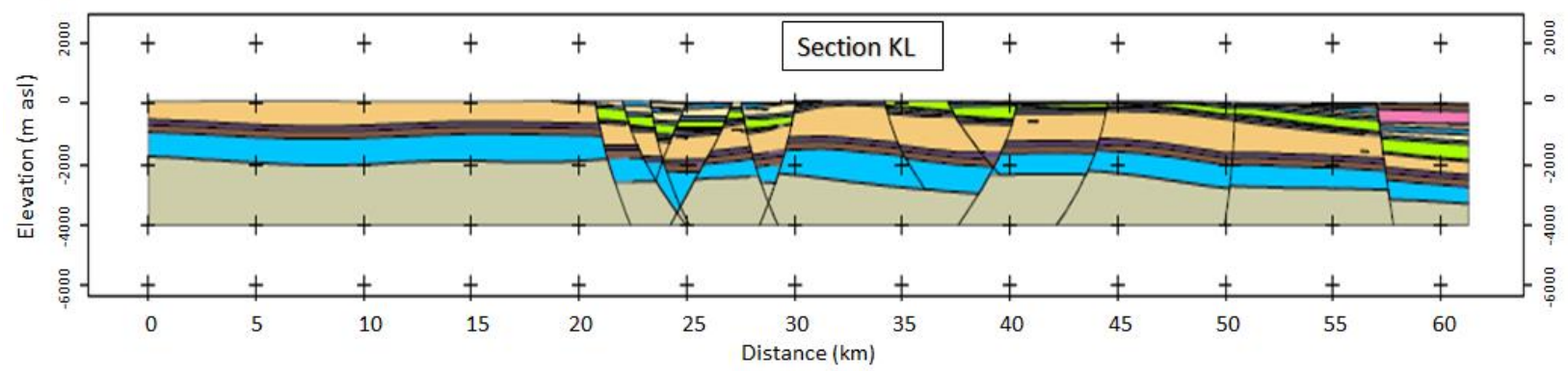

457 Fig. 2 (a) Geological map of the study area and (b) cross section passing through Ben Ghilouf, El Hamma, Mettouia 458 and Ghannouche. Aquifer 1: Qs : superficial Quaternary, Qj Gabes Jeffara Quaternary, Qr : intra-relief continental 459 Quaternary. N2s : lower Pleistocene. Aquifer 2 (Gabes North): N2inf : Pliocene, N1 : Serravallian, CM : 
460 Campanian. Sa : Santonian. Aquifer 3 (Gabes South) :

461 Turonian. AlCe : Cenomanian - upper Albian. Als : lower Albian. Ap : Aptian. Bas : upper Barremian - lower

462 Aptian. Be : lower Barremian. Aquifer 4 : Hs : Hauterivian - Valanginian. Bv : Berriasian-Valanginian. Aquifer 5 :

463 Js : upper Jurrassic. PM : Permo-Triassic
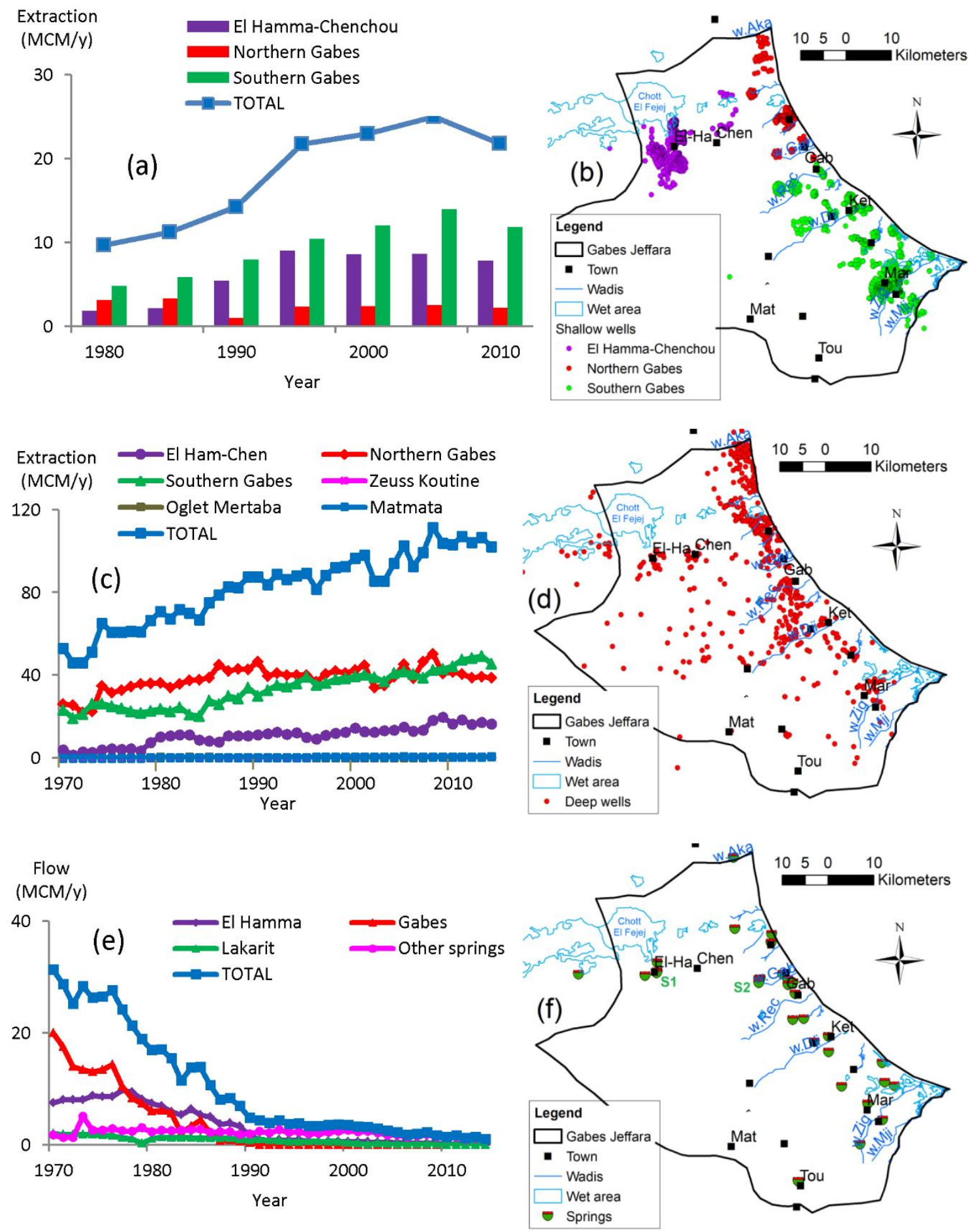

Fig. 3 Groundwater exploitation of shallow and deep aquifers: (a) Evolution of shallow aquifer exploitation; (b) Location of shallow wells; (c) Evolution of deep aquifer exploitation; (d) Location of deep wells; (e) Evolution of spring water flows; (f) Location of springs (S1: El Hamma; S2:Gabes). MCM: million cubic meters. Towns: El 

Matmata (Mat). Wadis: Akarit (Aka); Gabès (Gab); Djir (Dji); Zigzaou (Zig); Recifa (Rec); Mjirda (Mji)

\begin{tabular}{|c|c|c|c|c|}
\hline Level & Lithology & $\begin{array}{c}\text { Geological } \\
\text { log }\end{array}$ & $\begin{array}{c}\text { Hydrogeological } \\
\text { log }\end{array}$ & Conceptual model \\
\hline Quaternary & alluvium & Qs, Qj, Qr & 1 & aquifer 1 (phreatic) \\
\hline Lower Pleistocene & marls & N2s & 2 & \multirow{4}{*}{ aquifer 2 (Jeffara) } \\
\hline Pliocene & clay sands & N2i & 3 & \\
\hline Serravalien & sands & N1 & 4 & \\
\hline Campanian & limestones & $\mathrm{CM}$ & 5 & \\
\hline Santonian & marls & Sa & 6 & \\
\hline Carbonate Coniacian & limestones & $\mathrm{CoC}$ & 7 & \multirow{3}{*}{ aquifer 3 (Jeffara) } \\
\hline Marly Coniacian & marls & CoM & 8 & \\
\hline Turonian & limestones & Tu & 9 & \\
\hline Cenomanian - upper Albian & marls & AlCe & 10 & \\
\hline Lower Albian & sands & Als & 11 & \\
\hline Aptian & dolomite & Ap & 12 & \\
\hline Upper Barremian - Lower Aptian & sands, sandstone & Bas & 13 & \\
\hline Lower Barremian & clays, marls & $\mathrm{Be}$ & 14 & \\
\hline Hauterivian - Valanginian & sands, sandstone & $\mathrm{Hs}$ & 15 & aquifer $4(\mathrm{Cl})$ \\
\hline Berriasian - Valanginian & clays & Bv & 16 & \\
\hline Upper Jurassic & limestones & Js & 17 & aquifer 5 (ZK) \\
\hline Permo-Triassic & sandstones & PM & 18 & \\
\hline Legend of hydrogeological log & medium aquifer & major aquifer & medium aquitard & major aquitard \\
\hline
\end{tabular}

Fig. 4 Correspondence between the geological model and the hydrogeological model

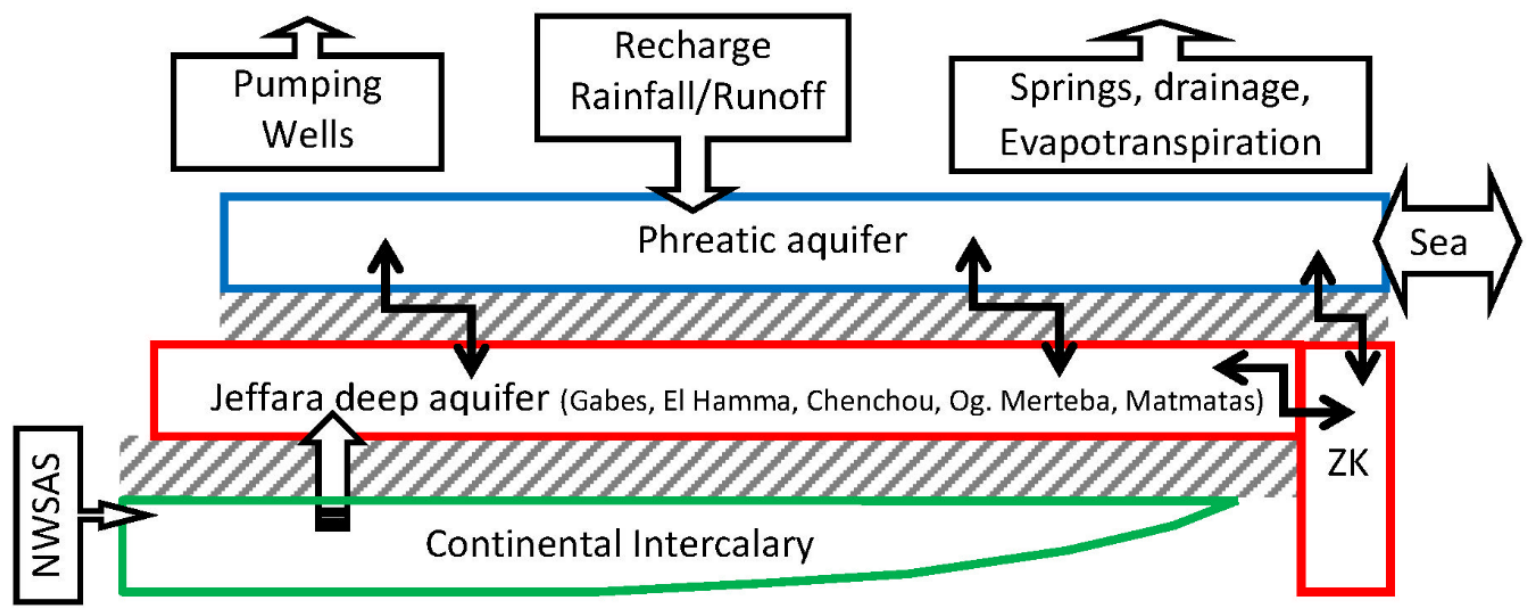

Fig. 5 Conceptual model of Gabes Jeffara aquifer system 


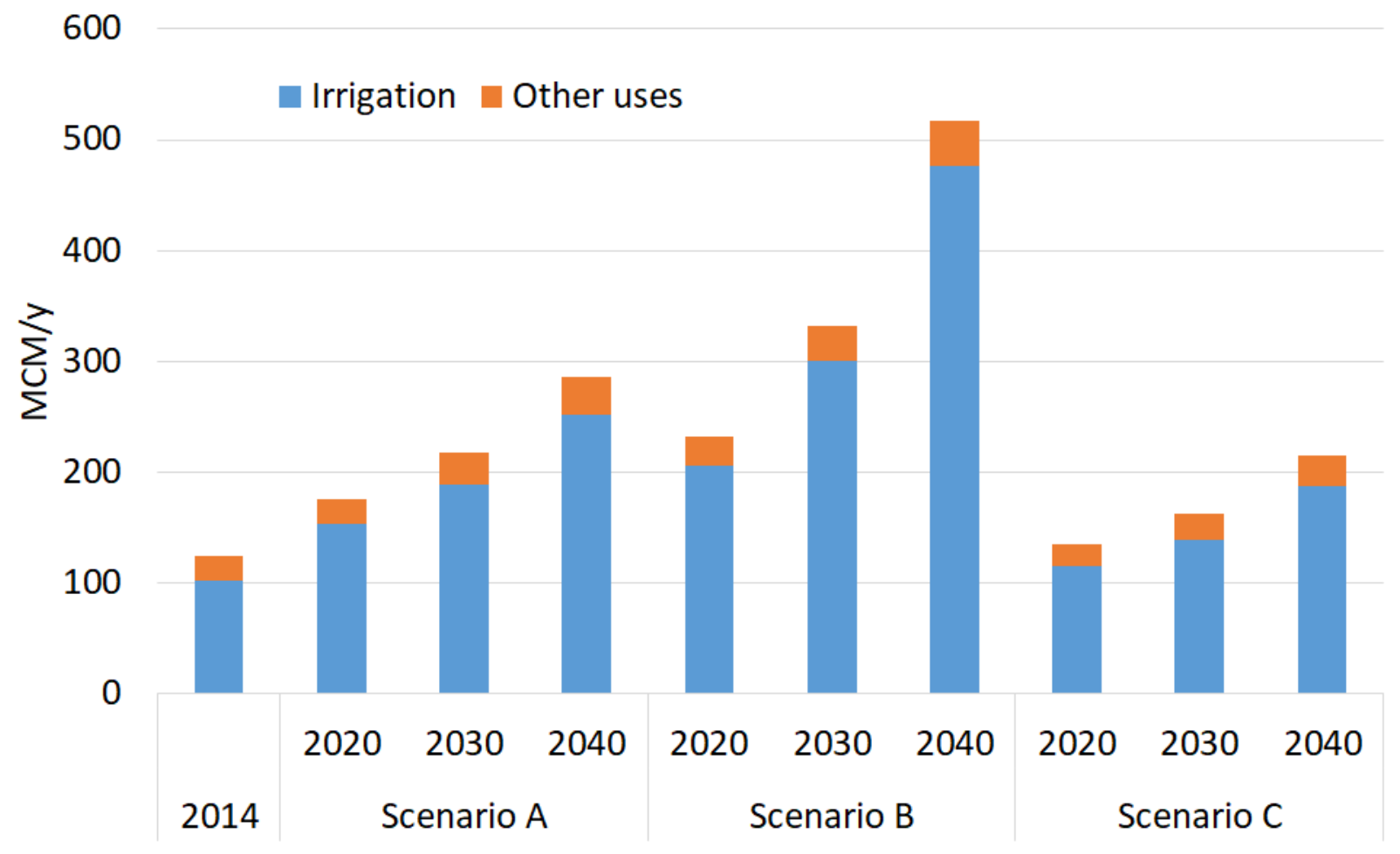

474

475 Fig. 6 Scenarios of future water demand 

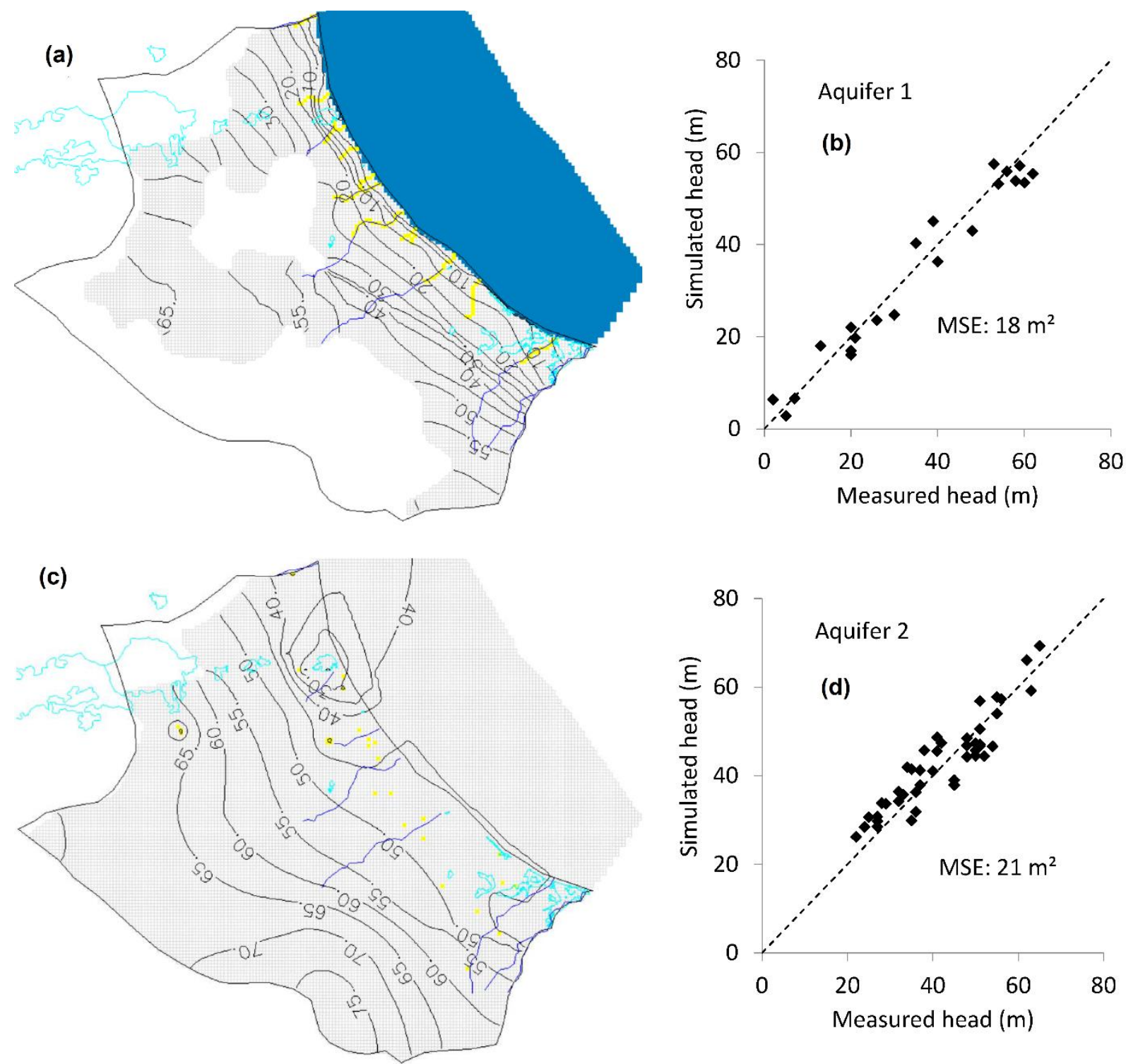

477 Fig. 7 Steady state calibration: (a) Simulated piezometric map of a shallow aquifer; (b) Simulated vs measured 478 heads for a shallow aquifer; (c) Simulated piezometric map of a deep aquifer; (d) Simulated vs measured heads for a deep aquifer 


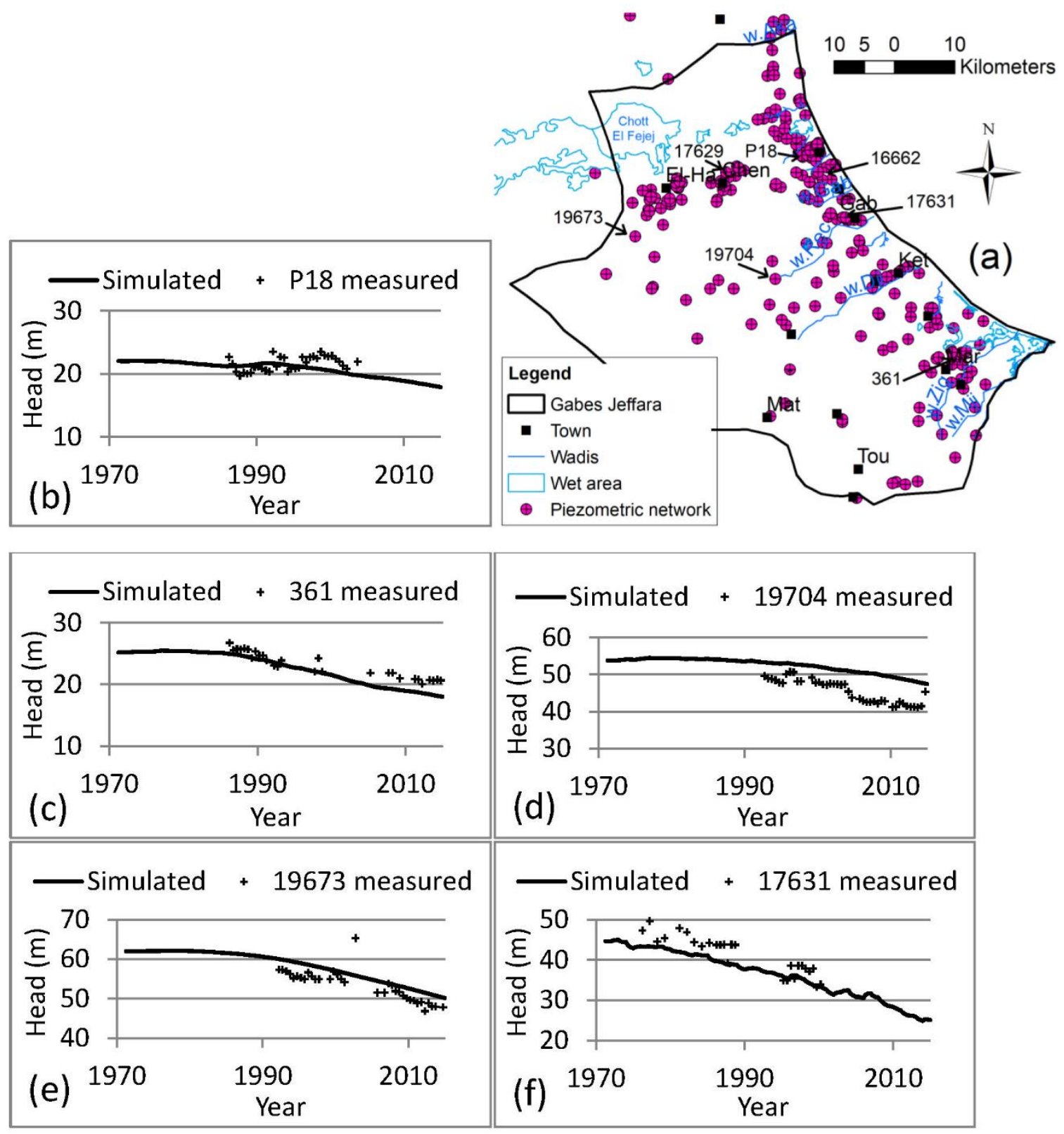

481 Fig. 8 (a) Location of groundwater level monitoring wells. Variation of simulated and measured heads at (b) well 482 P18, (c) well 361, (d) well 19704, (e) well 19673, and (f) well 17631 

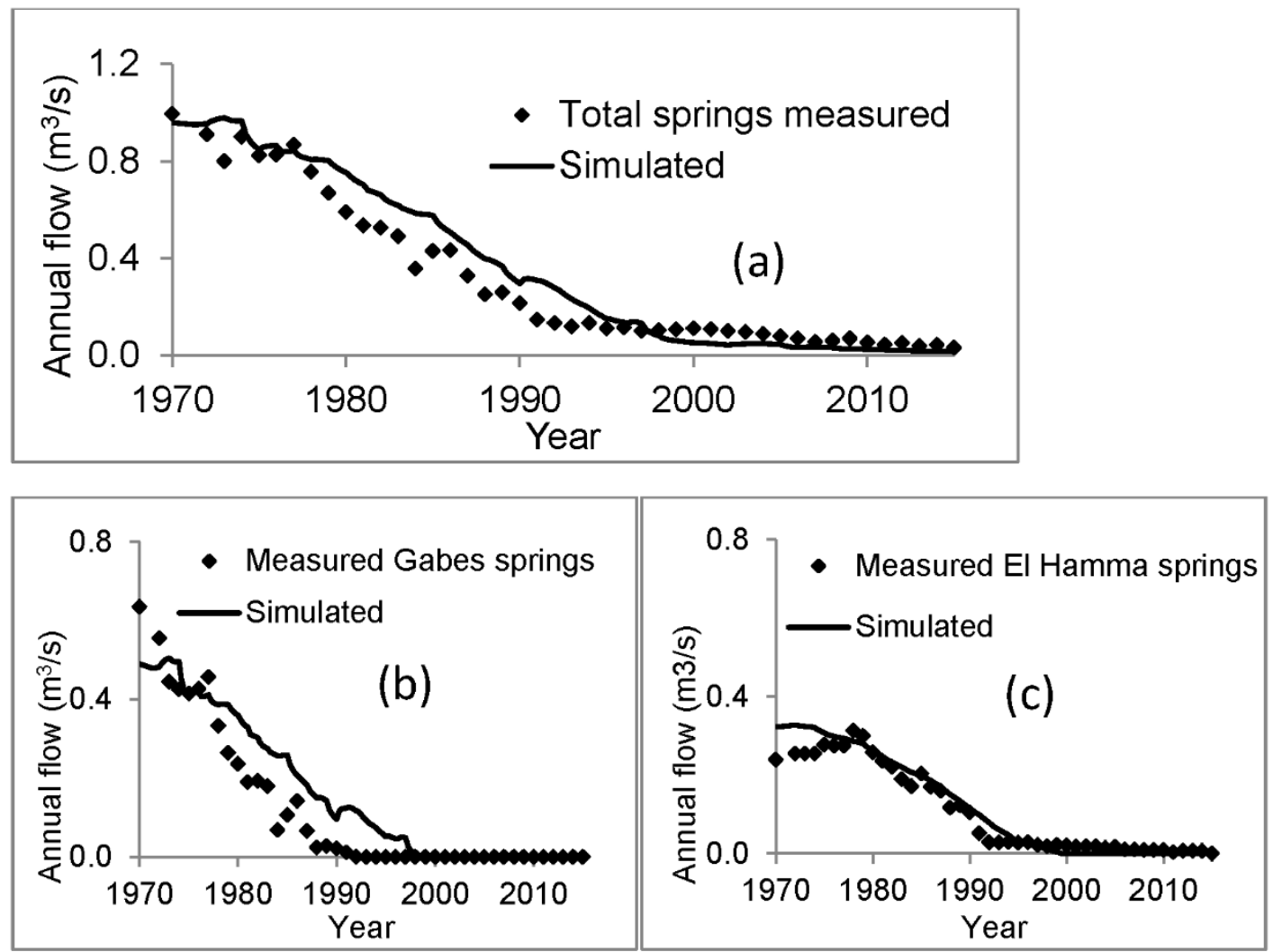

Fig. 9 Variation of simulated and measured spring flows: (a) total springs, (b) Gabes springs, and (c) El Hamma springs 


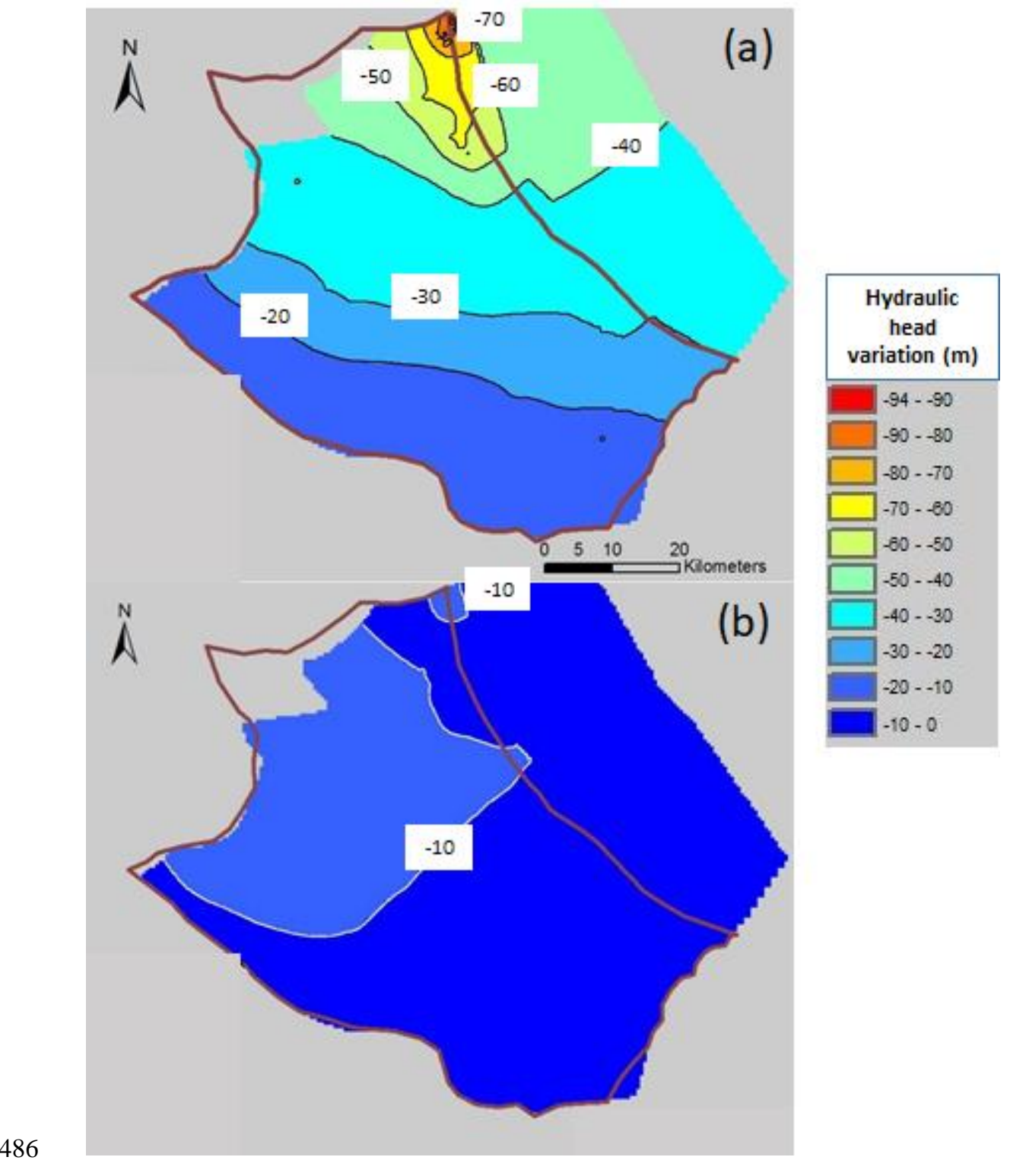

487 Fig. 10 Variations in simulated hydraulic heads in deep aquifers between 2040 and 2014 for (a) scenario 3 and (b) scenario 6 